\title{
ADVANTAGES OF IN VITRO CYTOTOXICITY TESTING BY USING PRIMARY RAT HEPATOCYTES IN COMPARISON WITH ESTABLISHED CELL LINES
}

\author{
Kun WANG ${ }^{1}$, Hidetoshi SHINDOH ${ }^{2}$, Tomoaki INOUE ${ }^{2}$ and Ikuo HORII ${ }^{2}$ \\ ${ }^{1}$ Department of Pharmacology, Dalian Medical University, \\ 465 Zhongshan Road, Dalian, 116027, P. R. China \\ ${ }^{2}$ Department of Preclinical Science, Nippon Roche Research Center \\ 200 Kajiwara, Kamakura City, Kanagawa 247-8530, Japan
}

(Received Jannuary 24, 2002; Accepted June 9, 2002)

\begin{abstract}
We investigated and compared the cytotoxicity of 16 reference compounds in four in vitro systems: primary cultured rat hepatocytes, hepatoma HepG2 cell line, non-hepatic HeLa and Balb/c $3 \mathrm{~T} 3$ cell lines. After $24 \mathrm{hr}$ of exposure to the test compounds, the water-soluble tetrazolium salts WST-1 assay was used as an endpoint to evaluate cytotoxicity. Acetaminophen, diclofenac sodium cyclophosphamide and disulfiram displayed from 2 to more than 10 times higher $\mathrm{IC}_{50}$ values in three cell lines than in rat primary cultured hepatocytes. The cytotoxic effects of aspirin, amiodarone, clorfibiric acid, chlorpromazine, erythomycin, lithocholic acid, cisplatin and quinidine in rat hepatocytes were similar or 2 times stronger than those observed in cell lines. Ketoconazole resulted in the lowest $\mathrm{IC}_{50}$ value in the HeLa cell line. The data suggested that the compounds which are known to be metabolism-mediated liver toxicants have a differential hepatotoxicity in vitro and that primary cultured rat hepatocytes could represent a valuable tool for both screening and study of the effects of bio-transformation on the cytotoxicity of new chemical entities and xenobiotics in vitro.
\end{abstract}

KEY WORDS: Cytotoxicity, In vitro, Primary cultured rat hepatocyte, HepG2 cell line, HeLa cell line, Balb/3T3 cell line, WST-1 assay

\section{INTRODUCTION}

Since the early 1990s, advances in chemistry, molecular biology and robotics in drug discovery have accelerated the process of drug discovery. Chemists have invented many new methodologies for production of large, diverse sets of new chemical entities (NCEs). From a practical viewpoint, this increase has produced enormous pressure in the pharmaceutical industry to determine which of these thousands of NCEs have drug-like properties. It is necessary to choose the NCEs with the most desirable characteristics in order to proceed with drug development. One of the factors to be considered at the early stage of drug discovery is the toxic potential of the NCEs. In vitro evaluation of the cytotoxic potential of NCEs may give an indication of the toxicity in vivo (Clothier et al., 1987, Fry et al.,
1990; Garle et al., 1994, Luber-Narod et al., 2001). Therefore, in vitro cytotoxicity screening is an invaluable tool to de-select compounds with undesirable properties.

The liver is an extremely powerful organ that elicits detoxification and removal of toxic chemicals and other materials, and is also frequently the target organ of toxins. The predominance of hepatocytes in terms of abundance and functional contribution to the liver has meant that primary hepatocyte cultures have been the prominent tool for in vitro studies. The primary cultured hepatocytes are well known as useful tools for investigating drug metabolism, induction of drugmetabolizing enzymes and cytotoxicity studies of chemicals. In recent years, many investigators have reported the characteristics of phase I and phase II drug-metabolizing enzymes and responsiveness to 
cytochrome P450-inducers in freshly isolated and cryopreserved human hepatocytes (Edward, 2001; Li et al., 1999; Silva et al., 1999). The primary cultured hepatocytes also appear to be the most powerful system for in vitro toxicology: screening of cytotoxic and genotoxic compounds, evaluation of chemoprotective agents, and determination of characteristic liver lesions and associated biochemical mechanisms induced by toxic compounds. This explains why numerous toxicity studies have been performed with isolated hepatocytes, either in suspension or in a primary culture (Ekwall and Acosta, 1982; Faber et al., 1988; Fautrel et al., 1991).

On the other hand, large numbers of cell lines with hepatic characteristics have been isolated from tumor cultures and immortalized by using recombinant constructs expressing oncogenes. Some hepatoma cell lines such as C3A and HepG2 retain a number of the biochemical synthesis pathways (Knowles et al., 1980). However, typical of continuous cell lines such as HeLa and 3T3, cell lines in general only express a limited range of Phase I and Phase II enzymes found in tissue hepatocytes (Fricker and Mundy, 1986; Perocco et al., 1997). Although established cell lines have been used in toxicity screening as well as for studies of toxic mechanisms, these cell lines cannot be used to screen cytotoxicity mediated by reactive metabolites due to their deficiency for certain metabolic functions, such as cytochrome P450 enzymes, or, even in some cell lines which retain enzyme activities, the activity may show variability over time in serial passages.

The present study has established a simple screening method to compare the sensitivity of primary cultured rat hepatocytes and three cell line systems, which differ in their drug metabolism capabilities, to various known toxic reference compounds with different toxic mechanisms.

\section{MATERIALS AND METHODS}

\section{Chemicals}

Acetaminophen, amiodarone hydrochloride, cyclophosphamide, phenytoin, isoniazide, erythromycin estolate, cisplatin, ketoconazole and disulfiram were purchased from Sigma Chemical Co. (Missouri, U.S.A.). Aspirin, lithocholic acid, diclofenac sodium, thioacetamide, chlorpromazine hydrochloride and quinidine were purchased from Wako Pure Chemical Co. (Osaka, Japan). Clofibric acid came from ICN Biomedicals Inc. (Ohio, U.S.A.).

\section{Cell isolation and culture}

Rat hepatocytes were isolated from male Sprague-Dawley rats (Japan SLC Inc., Shizuoka, Japan), weighing 180 to $280 \mathrm{~g}$ by the two-step in situ collagenase (Wako) perfusion method (Seglen, 1976). Rat hepatocytes were cultured in William's E culture medium (GibcoBRL, N.Y., U.S.A.) supplemented with10 mM HEPES buffer (pH 7.4), 10\% fetal calf serum (FCS, GibcoBRL), $10^{-6} \mathrm{M}$ dexamethasone (Sigma), $10^{-7} \mathrm{M}$ insulin (Sigma), $2 \mathrm{mM} \mathrm{L-glutamine}$ (GibcoBRL), $100 \mathrm{U} / \mathrm{ml}$ penicillin (GibcoBRL) and $100 \mu \mathrm{g} / \mathrm{ml}$ streptomycin (GibcoBRL). Initial cell viability assessed by Trypan blue stain $0.4 \%$ (GibcoBRL) exclusion was in excess of $80 \%$. Rat hepatocytes were seeded in 96-well type I collagen-coated plates (IWAKI, Tokyo, Japan) at $3 \times 10^{4}$ cells/well in $100 \mu \mathrm{l}$ of the culture medium and incubated at $37^{\circ} \mathrm{C}$, in $5 \% \mathrm{CO}_{2}$, 95\% air-humidified atmosphere for $3 \mathrm{hr}$ of cell attachment.

HepG2 cells and Balb/c 3T3 clone A31 (3T3) cells were obtained from ATCC (V.A., U.S.A.). HeLa cells were obtained from Dr. S. Adachi in Niigata University (Niigata, Japan). HepG2 cells were seeded in 96-well plates (Becton Dickinson Labware, N.J, USA) at $2 \times 10^{4}$ cells/well in $100 \mu \mathrm{l}$ of minimum essential medium (MEM, GibcoBRL) supplemented with $10 \%$ FCS, $10 \mathrm{mM}$ of HEPES buffer (pH 7.4), $100 \mathrm{U} / \mathrm{ml}$ of penicillin, $100 \mu \mathrm{g} / \mathrm{mL}$ of streptomycin, $0.1 \mathrm{mM}$ of nonessential amino acid (GibcoBRL) and $1 \mathrm{mM}$ of sodium pyrvate (GibcoBRL). Cells were incubated at $37^{\circ} \mathrm{C}$, in $5 \% \mathrm{CO}_{2}, 95 \%$ air-humidified atmosphere for $3 \mathrm{hr}$ spread and subconfluency. After 20 passages, HepG2 cells were no longer used for the test. The HeLa cell line was also investigated. HeLa cells were seeded in 96-well plates at $5 \times 10^{4}$ cells/well in $100 \mu$ of MEM supplemented with $10 \%$ FCS, $10 \mathrm{mM}$ of HEPES buffer ( $\mathrm{pH} 7.4), 100 \mathrm{U} / \mathrm{ml}$ of penicillin and $100 \mu \mathrm{g} / \mathrm{ml}$ of streptomycin. The cells were incubated at $37^{\circ} \mathrm{C}$, in $5 \%$ $\mathrm{CO}_{2}, 95 \%$ air-humidified atmosphere for $3 \mathrm{hr}$ spread and subconfluency. HeLa cells were not used for cytotoxicity screening after 20 passages.

3 T3 cell lines were seeded in 96-well plates at 1 $\times 10^{5}$ cells/well in $100 \mu \mathrm{l}$ of Dulbecco's modified Eagle's medium (GibcoBRL) supplemented with $10 \%$ calf serum, heat-inactivated (GibcoBRL), $10 \mathrm{mM}$ of HEPES buffer (pH 7.4), 2 mM L-glutamine, $100 \mathrm{U} / \mathrm{ml}$ of penicillin and $100 \mu \mathrm{g} / \mathrm{ml}$ of streptomycin. The cells were incubated at $37^{\circ} \mathrm{C}$, in $5 \% \mathrm{CO}_{2}, 95 \%$ air-humidified atmosphere for $3 \mathrm{hr}$ spread and subconfluency. After 20 passages, 3T3 lines were not used for cytotoxicity screening. 
Cytotoxicity in primary hepatocytes and cell lines.

Table 1. Comparison of $\mathrm{IC}_{50}(\mu \mathrm{M})$ values of reference compounds in various in vitro systems.

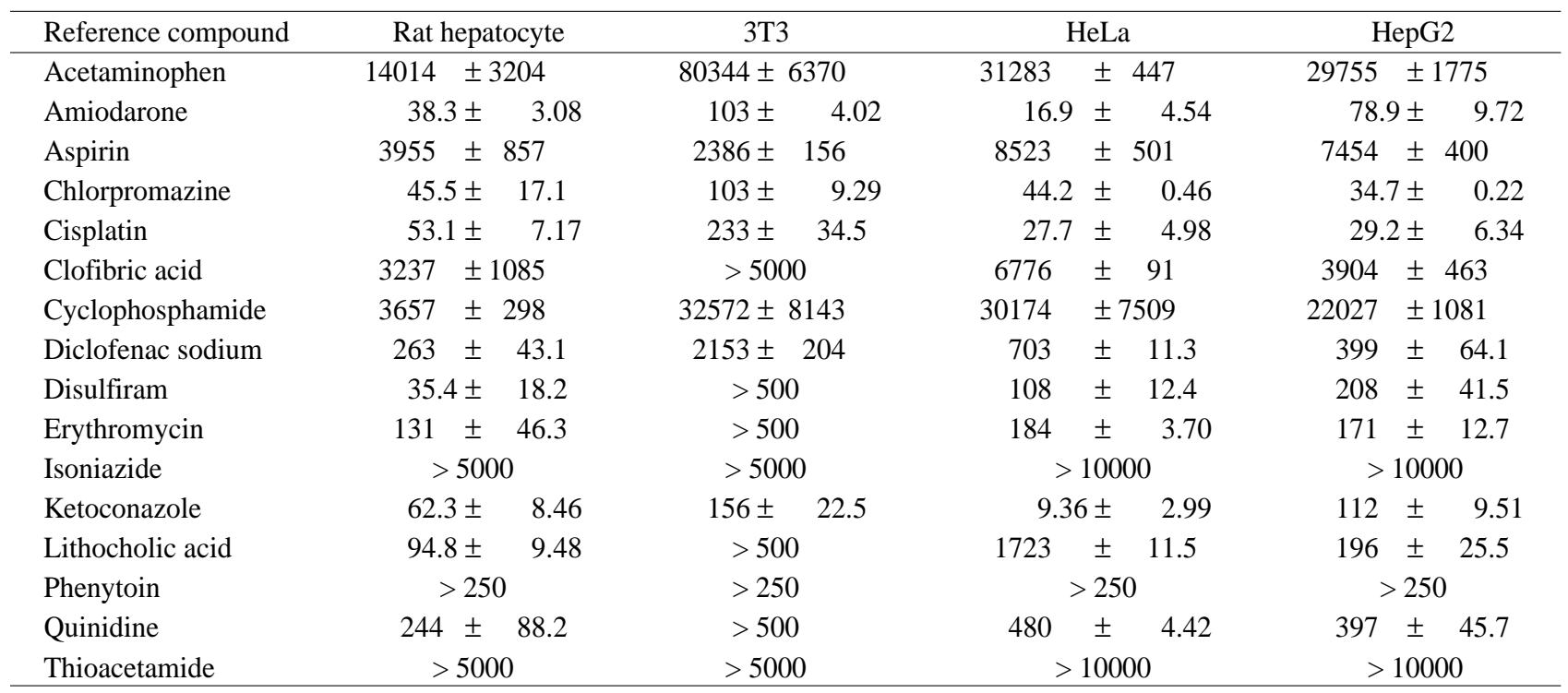

Values are given as the mean \pm SD of three experiments.

After $24 \mathrm{hr}$ exposure to the test compounds, cell viability was evaluated by WST-1 assay. IC50 values were calculated by the method described in MATERIALS AND METHODS.

\section{Cytotoxicity assay}

After $3 \mathrm{hr}$ cell attachment for rat hepatocytes, $3 \mathrm{hr}$ spreading and subconfluency for all HepG2, HeLa and $3 \mathrm{~T} 3$ cells, the cells were treated with various reference compounds. All of the reference compounds were dissolved in dimethylsulphoxide (DMSO, Wako) and tested at 11 concentrations in duplicate. The final concentration of DMSO in medium was $1 \%$ and was used at the same concentration (1\%) for all drug concentrations and blank. The exposure period was $24 \mathrm{hr}$. At the end of the incubation time, cell viability was evaluated with water-soluble tetrazolium salt WST-1 assay.

WST-1 reagent (Roche Molecular Biochemicals, Mannheim, Germany) is a slightly red solution that is reduced by mitochondrial dehydrogenases to form a soluble dark red formazan product. Only viable cells can metabolize significant amounts of WST-1, which leads to an increase in the amount of formazan dye that is quantified by a plate reader at $405 \mathrm{~nm}$ with reference at $630 \mathrm{~nm}$. For cells cultured in a 96-well plate, $10 \mu \mathrm{L}$ of WST-1 reagent was added directly to each well (1:10 final dilution), and the cells were incubated at $37^{\circ} \mathrm{C}$, in $5 \% \mathrm{CO}_{2}, 95 \%$ air-humidified atmosphere. After $1 \mathrm{hr}$ (for rat hepatocytes), $1.5 \mathrm{hr}$ (for HeLa and HepG2 cells) and 2 hr (for 3T3 cells) incubations with WST-1 reagent, the plate was stirred thoroughly for 15 sec on a shaker and the absorbance was measured. $\mathrm{IC}_{50}$ values were calculated from the concentrationresponse curves as the concentration of test compounds resulting in a decrease in absorbance equivalent to $50 \%$ of the control value.

\section{RESULTS AND DISCUSSION}

The aim of the current work was to investigate and compare the relative differences in the susceptibility of cytotoxicity among primary cultured rat hepatocytes, human hepatoma cell line HepG2, human cervix adenocarcinoma HeLa cells and mouse Balb/c 3T3 fibroblast cells. Sixteen reference compounds, which have differential cytotoxicity mechanisms, were tested in the four in vitro systems using the same endpoint assay. The concentrations that produced a 50\% inhibitory effect $\left(\mathrm{IC}_{50}\right)$ of 16 reference compounds, as measured by WST-1 assay in various in vitro systems, are listed in Table 1. The dose-response curves of three compounds - acetaminophen, cyclophosphamide and diclofenac sodium - are presented in Fig.1-3. According to $\mathrm{IC}_{50}$ values in Table 1, the compounds of acetaminophen, cyclophosphamide, diclofenac sodium and disulfiram displayed $\mathrm{IC}_{50}$ values 2 to 13 times higher in the three cell lines than those in rat primary 


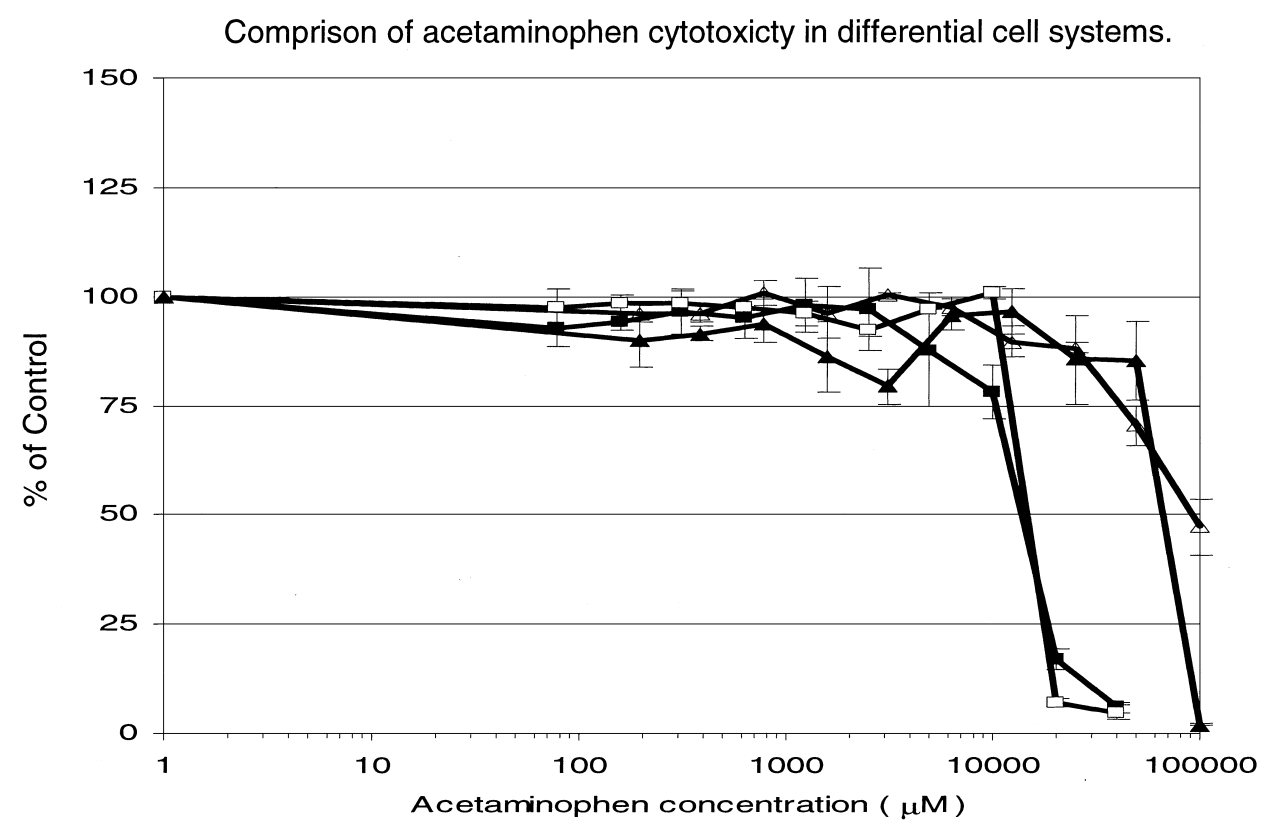

Fig.1. Dose-response curve of acetaminophen in differential in vitro systems. Cells were exposed to several concentrations of acetaminophen for $24 \mathrm{hr}$. After treatment, viability was evaluated by WST-1 assay. Data represent the mean of three experiments \pm SD. If not visible, bars are inside the symbols. Acetaminophen: ( $\boldsymbol{\square})$ in primary cultured rat hepatocytes; $(\square)$ in Hela cell line; $(\Delta)$ in $3 \mathrm{~T} 3$ cell line; $(\triangle)$ in HepG2 cell line.

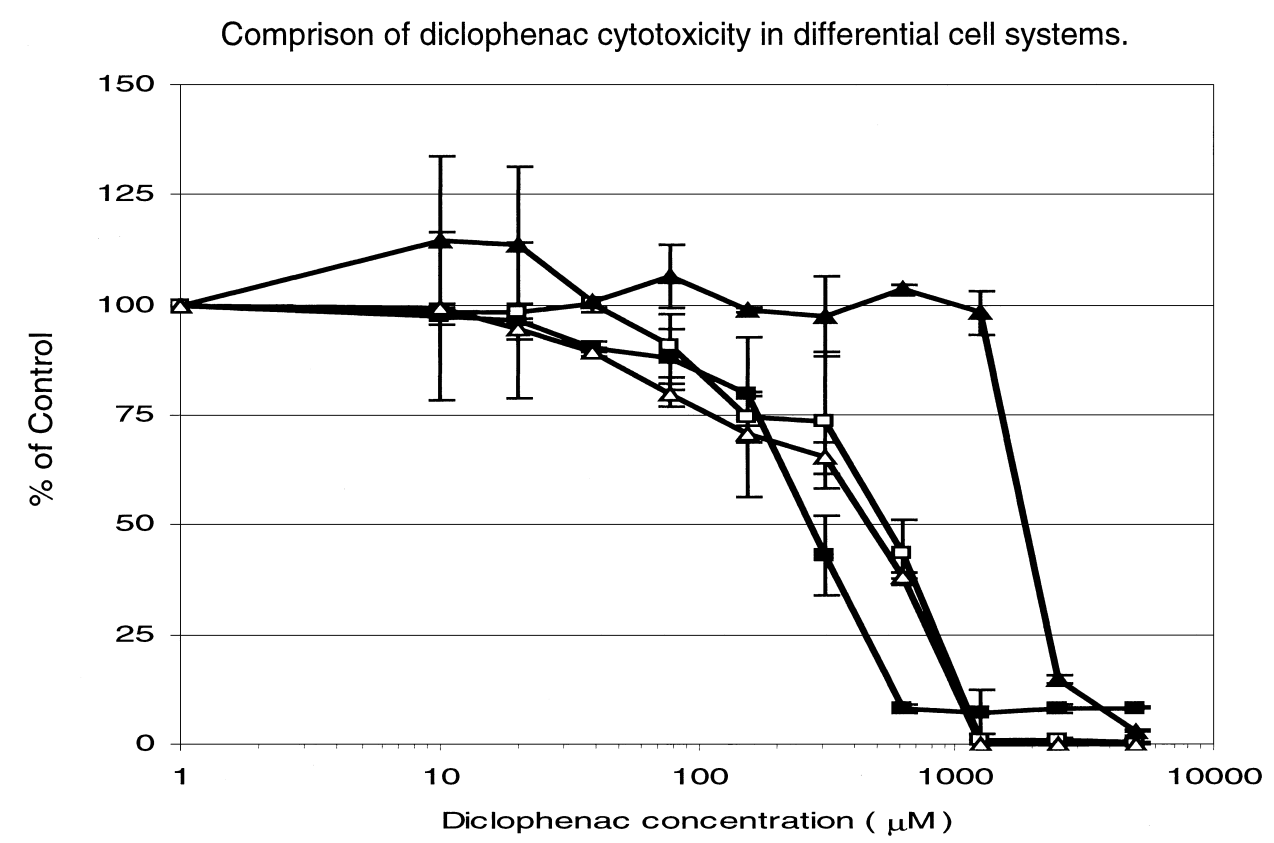

Fig.2. Dose-response curve of diclofenac in differential in vitro systems. Cells were exposed to several concentrations of diclofenac for $24 \mathrm{hr}$. After treatment, cell viability was evaluated by WST-1 assay. Data represent the mean of three experiments $\pm \mathrm{SD}$.

If not shown, bars are inside the symbols. Diclofenac: $(\boldsymbol{\square})$ in primary cultured rat hepatocytes, $(\square)$ in Hela cell line; $(\boldsymbol{\Delta})$ in $3 \mathrm{~T} 3$ cell line; $(\triangle)$ in HepG2 cell line. 
Cytotoxicity in primary hepatocytes and cell lines.

Comperison of cyclophosphamide cytotoxicity in differential cell systems.

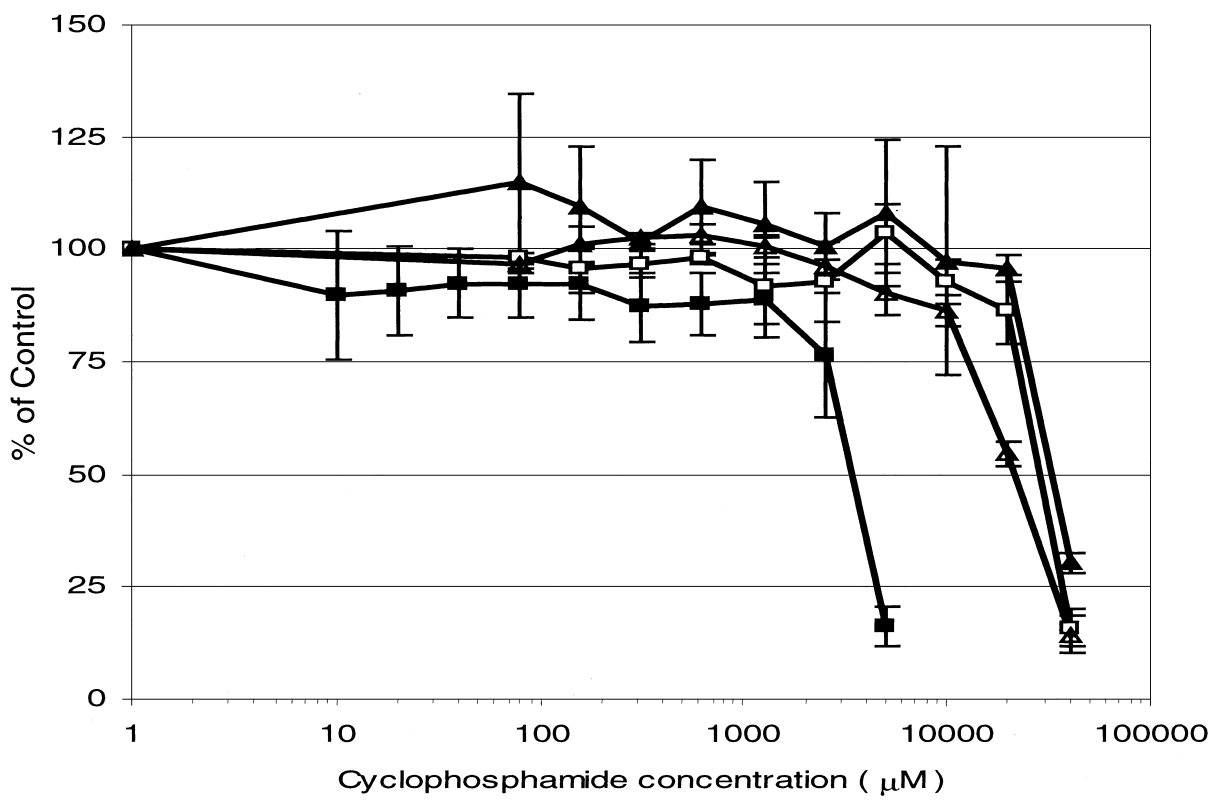

Fig.3. Dose-response curve of cyclophosphamide in differential in vitro systems. Cells were exposed to several concentrations of cyclophosphamide for $24 \mathrm{hr}$. After treatment, viability was evaluated by WST-1 assay. Data represent the mean of three experiments \pm SD. If not visible, bars are inside the symbols. Cyclophosphamide: ( $\boldsymbol{\square})$ in primary cultured rat hepatocytes; $(\square)$ in Hela cell line; $(\boldsymbol{\Delta})$ in $3 \mathrm{~T} 3$ cell line; $(\triangle)$ in HepG2 cell line.

cultured hepatocytes, with the following $\mathrm{IC}_{50}$ values of $14014 \mu \mathrm{M}, 3657 \mu \mathrm{M}, 263 \mu \mathrm{M}, 35 \mu \mathrm{M}$ in hepatocyte, $31284 \mu \mathrm{M}, 30174 \mu \mathrm{M}, 703 \mu \mathrm{M}, 108 \mu \mathrm{M}$ in the HeLa cell line; $29755 \mu \mathrm{M}, 22027 \mu \mathrm{M}, 399 \mu \mathrm{M}, 208 \mu \mathrm{M}$ in the HepG2 cell line; and $80344 \mu \mathrm{M}, 32572 \mu \mathrm{M}, 2153$ $\mu \mathrm{M},>500 \mu \mathrm{M}$ in the $3 \mathrm{~T} 3$ cell line, respectively. The cytotoxic effects of amiodarone, aspirin, clofibiric acid, lithocholic acid chlorpromazine, erythromycin, cisplatin and quinidine in rat primary hepatocytes were similar or 2 times stronger than those observed in the cell lines. Ketoconazole resulted in the lowest $\mathrm{IC}_{50}$ value in the HeLa cell line. Phenytoin, isoniazide and thioacetamide had no toxicity at the test concentrations in all of the four in vitro systems.

Almost all of the compounds tested exhibited a rough similarity (differences were generally less than threefold) of $\mathrm{IC}_{50}$ values in the four cell cultures, which indicates a "basal cytotoxicity" as proposed by Ekwall (1983). It was suggested that for most chemicals, toxicity is a consequence of non-specific alterations in cellular functions. Evaluation of the cytotoxic potential of compounds may therefore give an indication of the acute toxic potential in vivo. A comparison of the results from rat hepatocytes and the cell lines demonstrated that acetaminophen, diclofenac, cyclophosphamide, and disulfiram are comparatively more toxic to primary cultured rat hepatocytes than to the other cell types. Three of the four compounds, especially acetaminophen, are known to act by producing metabolites more toxic to the hepatocytes (Albano et al., 1985; Schmitz et al., 1995; Roque et al., 1998). As an alternative interpretation, the increased cytotoxicity of three compounds could be taken as an indication of specific liver injury, which is known to occur at present for some compounds. The hepatocyte is the center of active chemical biotransformation in the liver, although some metabolic enzymes are also found in endothelial cells, Kupffer cells and bile duct cells (Steinberge et al., 1987). Hepatocytes mediate activation and detoxification reactions through Phase I and Phase II enzymes. In the course of biotransformation, some xenobiotics are catalyzed both by cytochrome P450 and by conjugation enzymes, and are biotransformed into reactive metabolites that are usually more toxic than their parent compounds. This activation process is the key to some hepatotoxic phenomena. Indeed, in rat hepatocytes, the $\mathrm{IC}_{50}$ values of the three compounds, acetaminophen, diclofenac and cyclo- 
phosphamide, were just 3 times or less lower than those observed in HeLa and HepG2, but more than 5, 8 and about 9 times higher $\mathrm{IC}_{50}$ values (less cytotoxic effects) were found in $3 \mathrm{~T} 3$ cells for acetaminophen, diclofenac sodium and cyclophosphamide, respectively. The relatively similar toxic effects among primary cultured rat hepatocytes, HeLa and HepG2 cells may depend on the following factors. With regard to acetaminophen, the incubation time of $24 \mathrm{hr}$ may be too short to reflect the 2-4 days' delay that occurs in the production of clinic liver injury by acetaminophen. At a toxic dose, CYP2E1 is found to be the most efficient catalyst for the bioactivation of acetaminophen to NAPQI ( $N$-acetyl-p-benzoquinone imine) (Chen et al., 1998), which causes depletion of GSH and protein thiols and arylation of the latter, but in rat hepatocytes the contents of CYP2E1 are relatively lower. Furthermore, the significant formation of non-toxic metabolite 3hydroxyacetaminophen in rats by various cytochrome P450 enzymes involved in the oxidation of acetaminophen may have an important role for the lower sensitivity of rat hepatocytes compared to that of the mouse (To and Wells, 1985; Harvison et al.,1986; Patten et al.,1993; Zand et al., 1998). Diclofenac, which is a nonsteroidal anti-inflammatory drug, undergoes bioactivation via CYP2C enzyme to the formation of reactive metabolites, benzoquinone and imine intermediate, of which the latter contributes to diclofenac hepatic injury (Tang et al., 1999). Bort et al. (1999) also found that diclofenac was more cytotoxic to rat and human primary cultured hepatocytes capable of metabolizing drugs than to non-metabolizing cell lines, HepG2 and $\mathrm{FaO}$. Our results were in line with the above observations: in non-metabolizing cells, especially in $3 \mathrm{~T} 3$ cells, diclofenac had a higher $\mathrm{IC}_{50}$ value (more than 8 times) than that found in rat hepatocytes. Also, for cyclophosphamide, the cytotoxicity is known for the activation mediated by liver CYP2B (Horner et al., 1985; Bull et al., 2001). Similar results were observed in our experiment. The $24 \mathrm{hr}$ exposure to cyclophosphamide led to an almost 9 times stronger cytotoxic effect to rat primary cultured hepatocytes as compared with that observed in cell lines. Disulfiram had a more than 10 times lower $\mathrm{IC}_{50}$ value in rat hepatocytes than in the $3 \mathrm{~T} 3$ cell line. The reason is not clear in the present experiment.

After isolation, rat hepatoctytes attach to the plastic surfaces and form an epithelial monolayer (Maurice et al., 1988). Numerous hepatocyte functions remain in vitro such as Na-dependent transport functions for bile acid (Schwarz et al., 1975), amino acids (Kilberg,
1982), and sugars (Baur and Heldt, 1977). However, hepatocytes tend to lose their functionality early and rapidly during isolation and subsequent primary cultures. Loss of cytochrome P450 occurs in up to $50 \%$ in rat hepatocytes during the first $24-48 \mathrm{hr}$ in vitro (Begue et al., 1984). Similar changes are observed for Phase II enzymes (Forster et al.,1986; Vandenberghe et al.,1988). Other liver-specific genes such as albumin and transferrin in vitro may fall to less than $10 \%$ of their transcription rate in vivo (Clayton and Darnell, 1983; Fraslin et al., 1985). Various investigators are continuing to work on a further and better understanding of the molecular basis of the above process, and new hepatocyte cell lines have been developed (Werner et al., 1999; Allen et al., 2000; Kobayashi et al., 2000; Lee et al., 2000) in an effort to minimize the limitations of primary cultured hepatocytes. Unfortunately, up to now, there do not appear to be any continuous cell lines that can provide the full range of activities identified in primary hepatocyte cultures. However, care should be taken with cell lines, as they have been reported to show progressively de-differentiated characteristics after multiple passages (Kim et al., 2000). There is also the possibility that hepatic cell lines have been crosscontaminated with other cells (Stacey et al., 1993). Finally, the ultimate goal of in vitro experiments is to generate the scientific information that would identify NCEs that are potentially toxic to man. The data from primary cultured rat hepatocytes are helpful in rational species extrapolation of toxic effects from animal to human, especially now as access to human liver tissue or freshly isolated human hepatocytes is limited due to ethical, economic and technical reasons. At the present time, the primary cultured hepatocytes may be the most favored method to detect metabolism-mediated cytotoxicity. However, the following aspects should be taken into consideration to evaluate cytotoxicities in rat primary hepatocytes for extrapolation to humans: (1) gender differences in the activities and contents of cytochrome $\mathrm{P} 450$ subfamilies in rats (e.g. the activity of CYP2C11 in male rats is higher than that in female rats, etc.) (Czerniak, 2001); and (2) differences of metabolic rates between rat and human hepatocytes (Turesky et al., 2001). Both the concentration and the period of exposure to test compounds are affected by differences of the metabolic rates in rat and human hepatocytes. Moreover, the free fractions of the test compounds might be different depending on the degree of binding to the fetal calf serum added into the culture medium. Thus, information on species differences in the metabolic activities and extent of exposure to free 
Cytotoxicity in primary hepatocytes and cell lines.

fraction of the test compounds in the in vitro cytotoxicity assays would give a more accurate extrapolation of the toxicities in humans.

In summary, our results demonstrated that compounds such as acetaminophen, diclfoenac and cyclophosphamide, which are known to exhibit cytotoxicity via metabolism-mediated activation, had differential in vitro cytotoxic effects on primary cultured rat hepatocytes in comparison with non-metabolizing cells: HepG2 and HeLa cells, especially 3T3 cells which have no hepatic metabolizing activities. Rat primary cultured hepatocytes could represent a valuable tool for both screening and study of the effects of biotransformation on the toxicity of both NCEs and xenobiotics in vitro.

\section{ACKNOWLEDGMENT}

The authors would like to thank the entire staff of the Department of Preclinical Science in Nippon Roche Research Center for their kind help.

\section{REFERENCES}

Albano, E., Rundrgren, M., Harvison, P.J., Nelson, S.D. and Moldeus, P. (1985): Mechanisms of $N$ acetyl- $p$-benzo-quinone imine cytotoxicity. Mol. Pharmacol., 28, 306-311.

Allen, K.J., Reyes, R., Demmler, K., Mercer, J.F., Williamson, R. and Whitehead, R.H. (2000): Conditionally immortalized mouse hepatocytes for use in liver gene therapy. J. Gastroenterol. Hepatology, 15, 1325-1332.

Baur, H. and Heldt, H.W. (1977): Transport of hexoses across the liver cell membrane. Eur. J. Biochem., 74, 397-403.

Begue, J.M., Guguen-Guillouzo, C., Pasdeloup, N. and Guillouzo, A. (1984): Prolonged maintenance of active cytochrome P-450 in adult rat hepatocytes co-culture with another liver cell type. Hepatology, 4, 839-842.

Bort, R., Ponsoda, X., Jover, R., Gomez-Lechon, J. and Castell, J.V. (1999): Diclofenac toxicity to hepatocytes: A role for drug metabolism in cell toxicity. J. Pharmacol. Exp. Ther., 288, 65-72.

Bull, S., Langezaal, I., Clothier, R. and Coecke, S. (2001): A genetically engineered cell-based system for detecting metabolism-mediated toxicity. Alter. Lab. Anim., 29, 703-719.
Chen, W., Koenigs, L.L., Thompson, S.J., Peter, R.M., Rettie, A.E., Trager, W.F. and Nelson, S.D. (1998): Oxidation of acetaminophen to its toxic quinone imine and non-toxic catechol metabolites by baculovirus-expressed and purified human cytochromes 2E1 and 2A6. Chem. Res. Toxicol., 11, 295-301.

Clayton, D.F. and Darnell, J.E. (1983): Changes in liver specific compared to common gene transcription during primary culture of mouse hepatocytes. Mol. Cell. Biol., 3, 1552- 2561.

Clothier, R.H., Humlme, L.M., Smith, M. and Balls, M. (1987): Comparison of the in vitro cytotoxicities and acute in vivo toxicities of 59 chemicals. Mol. Toxicol., 1, 571-577.

Czerniak, R. (2001): Gender-based differences in pharmacokinetics in laboratory animal models. Int. J. Toxicol., 20, 161-163.

Edward, L.L. (2001): Human hepatocyte culture systems for the in vitro evaluation of cytochrome P450 expression and regulation. Eur. J. Pharm. Sci., 13, 343-368.

Ekwall, B. and Acosta, D. (1982): In vitro comparative toxicity of selected drugs and chemicals in Hela cells, Chang liver cells, and rat hepatocytes. Drug Chem. Toxicol., 5, 219-31.

Ekwall, B. (1983): Screening of toxic compounds in mammalian cell cultures. Ann. N.Y. Acad. Sci., 407, 64-77.

Fabre, G., Rahmanl, R., Placidi, M., Combalbert, J., Cov, j., Cano, J.-P., Coulange, C., Ducros, M. and Rampal, M. (1988): Characterization of midazolam metabolism using human hepatic microsomal fractions and hepatocytes in suspension obtained by perfusion whole human livers. Biochem. Pharmacol., 37, 4389-4397.

Fautrel, A., Chesne, C., Guilouzo, A., De Sousa, G., Placidi, M., Rahmani, R., Braut, F., Pichon, J. and Hoellinger, H. (1991): A multicentre study of acute in vitro cytotoxicity in rat liver cells. Toxicol. In Vitro, 5, 543-547.

Forster, U., Luippold, G. and Schwartz, L.R. (1986): Induction of monoxygenase and UDP-glucuronyltransferase activities in primary cultures of rat hepatocytes. Drug Metab. Dispos., 4, 353360.

Fraslin, J.M., Kneip, B., Vaulont, S., Glaise, D., Munnich, A. and Guguen-Guilouzo, C. (1985): Dependence of hepatocyte specific gene expression on cell-cell interactions in primary culture. EMBO J., 4, 2487-2491. 
Fricker, S.P. and Mundy, G.R. (1986): A cytotoxicity assay in vitro with a liver metabolizing system as a screen for anti-cancer agents. Biochem. Soc. Trans., 14, 693-694.

Fry, J.R., Garle, M.J., Hammond, A.H. and Hatfield, A. (1990): Correlation of acute lethal potency with in vitro cytotoxicity. Toxicol. In Vitro, $\mathbf{4}$, 175-178.

Garle, M.J., Fentem, J.H. and Fry, J.R. (1994): In vitro cytocoxicity tests for the prediction of acute toxicity in vivo. Toxicol. In Vitro, 8, 1303-1312.

Harvsion, P.J., Forte, A.J. and Nelson, S.D. (1986): Comparative toxicities and analgesic activities of three monomethylated analogues of acetaminophen. J. Med. Chem., 29, 1737-1743.

Horner, S.A., Fry, J.R., Clothier, R.H. and Balls, M. (1985): A comparison of two cytotoxicity assays for the detection of metabolism-mediated toxicity in vitro: A study with cyclophosphamide. Xenobiotica, 15, 681-687.

Kilberge, M.S. (1982): Amino acid transport in isolated rat hepatocytes. J. Member. Biol., 69, 112.

Kim, B.H., Sung, S.R., Choi, E.H., Kim, Y.I., Kim, K.J., Chang, Y.W., Lee, J.I. and Chang, R. (2000): Dedifferentiation of conditionally immortalized hepatocytes with long-term in vitro passage. Exp. Mol. Med., 32, 29-37.

Knowles, B.B., Howe, C.C. and Aden, D.P. (1980): Human hepatocellular carcinoma cell lines secrete the major plasma proteins and hepatitis B surface antigen. Science, 209, 497-499.

Kobayashi, N., Noguchi, H., Fujiwara, T., Westerman, K.A., Leboulch, P. and Tanaka, N. (2000): Establishment of a highly differentiated immortalized adult human hepatocyte cell line by retroviral gene transfer. Transplant Proc., 32, 2368-2369.

Lee, J.H., Kim, W.H., Park, H., Yun, C., Kim, B.H., Kwak, S.J., Cho, H. and Kim, M.W. (2000): Production and characterization of immortalized rat hepatocytes secreting hepatocyte growth factor/scatter factor. Hepato-Gastroenterol., 47, 978-983.

Li, A.P., Lu, C., Brent, J.A., Pham, C., Fackett, A., Ruegg, C.E. and Silber, P.M. (1999): Cryopreserved human hepatocytes: Characterization of drug-metabolizing enzyme activities and applications in higher throughput screening assays for hepatotoxicity, metabolic stability and drug- drug interaction potential. Chem. Biol. Interact., 121, 17-35.

Luber-Narod, J., Smith, B., Grant, W., Jimeno, J.M., Lopez-Lazaro, L. and Faircloth, G.T. (2001): Evaluation of the use of in vitro methodologies as tools for screening new compound for potential in vivo toxicity. Toxicol. In Vitro, 15, 571577.

Maurice, M.E., Rogier, E., Cassio, D. and Feldmann, G. (1988): Formation of plasma membrane domains in rat hepatocytes and hepatoma cell lines in culture. J. Cell Sci., 90, 79-92.

Patten, C.J., Thomas, P.E., Guy, R.L., Lee, M., Gonzalez, F.J., Guengerich, F.P. and Yang, C.S. (1993): Cytochrome P450 enzymes involved in acetaminophen activation by rat liver microsomes and their kinetics. Chem. Res. Toxicol., 6, 511-518.

Perocco, P., Del Ciello, C., Mazzullo, M., Rocchi, P., Ferreri, A.M., Paolini, M., Pozzelli, L. and Cantelli-Forti, G. (1997): Cytotoxic and cell transforming activities of the fungicide methyl thiophanate on $\mathrm{BALB} / \mathrm{c} 3 \mathrm{~T} 3$ cells in vitro. Mutat. Res., 394, 29-35.

Roque, B., Xavier P., Ramiro, J.M., Jose, G.L. and Jose, V.C. (1998): Diclophenac toxicity to hepatocytes: A role for drug metabolism in cell toxicity. J. Pharmacol. Exper. Therap., 288, 65-72.

Schwarz, L.R., Burr, R., Schwese, E., Pfaff, E. and Greim, H. (1975): Uptake of taurocholic acid into isolated rat liver cells. Eur. J. Biochem., 55, 617-623.

Schmitz, G., Stauffert, I., Sippel, H., Lepper, H. and Estler, C.J. (1995): Toxicity of diclofenac to isolated hepatocytes. J. Hepatol., 14, 408-409.

Selgen, P.O. (1976): Preparation of isolated rat liver cells. Meth. Cell Biol., 13, 29-83.

Silva, J.M., Day, S.H. and Nicoll-Griffith, D.A. (1999): Induction of cytochrome-P450 in cryopreserved rat and human hepatocytes. Chem. Biol. Interact., 121, 49-63.

Stacey, G.N., Bolton, B.J. and Doyle, A. (1993): Multifocus fingerprinting used for definitive Hela cell clones. In vitro Cell Develop. Biol., 29A, 123.

Steinberge, P., Lafranconi, W.M., Wolf, R.W., Waxman, D.J., Oesch, F. and Friedberg, T. (1987): Xenobiotic metabolizing enzymes are not restricted in parenchymal cells in rat liver. Mol. Pharmacol., 32, 463-470. 
Cytotoxicity in primary hepatocytes and cell lines.

Tang, W., Stearns, R.A., Bandiera, S.M., Zhang, Y., Raab, C., Braun, M.P., Dean, D.C., Pang, J., Leung, K.H., Doss, G.A., Strauss, J.R., Kwei, G.Y., Rushmore, T.H., Chiu, S.-H.L. and Baillie, T.A. (1999): Studies on cytochrome P-450mediated bioactivation of diclofenac in rats and human hepatocytes: Identification of glutathione conjugated metabolites. Drug Metab. Dispos., 27, 365-372.

To, E.C. and Wells, P.G. (1985): Repetitive microvolumetric sampling and analysis of acetaminophen and its toxicologically relevant metabolites in murine plasma and urine using high performance liquid chromatograph. J. Anal. Toxicol., 9, 217-221.

Turesky, R.J., Parisod, V., Huynh-Ba, T., Langoueet, S. and Guengerich, F.P. (2001): Regioselective differences in $\mathrm{C} 8$ - and $\mathrm{N}$-oxidation of 20amino3,8-dimethylimidazo[4,5-f]quinoxaline by human and rat liver microsomes and cytochrome P450 1A2. Chem. Res. Toxicol., 14, 901-911.

Vandenberghe, Y., Glaise, D., Meyer, D.J., Guillouzo, A. and Ketterer, B. (1988): Glutathione transferase isoenzymes in cultured rat hepatocytes. Biochem. Pharmacol., 37, 2482-2485.

Werner, A., Duvar, S., Muthing, J., Buntemeyer, H., Kahmann, U., Lundsdorf, H. and Lehmann, J. (1999): Cultivation and characterisation of a new immortalised human hepatocyte cell line, HepZ, for use in an artificial liver support system. Ann. N. Y. Acad. Sci., 875, 364-368.

Zand, H., Buters, J.T.M., Ward, J.M., Bruno, M.K., Lucas, A.M., Stern, S.T. and Gonzalez, F.J. (1998): Protection against acetaminophen toxicity in CYP1A2 and CYP2E1 double-null mice. Toxicol. Appl. Pharmacol., 152, 193-199. 